\title{
A PERTINÊNCIA DA SOCIOLOGIA DE ALAIN TOURAINE
}

No livro Qu'est-ce que la démocratie, publicado em 1994, Alain Touraine parece descrever a situação que vivemos atualmente:

Muitos sinais podem nos levar a crer atualmente que os regimes que consideramos como democráticos se enfraquecem, assim como os regimes autoritários, e se submetem às exigências do mercado mundial protegido e regulado pelo poder dos Estados Unidos e por acordos entre os três centros principais do poder econômico. Este mercado mundial tolera a participação de países que têm governos autoritários fortes, ou regimes autoritários em decomposição, ou ainda regimes oligárquicos, e finalmente regimes que podemos chamar de democráticos, ou seja nos quais os governados escolhem livremente os governantes que os representam. Este recuo dos Estados, democráticos ou não, acarreta uma diminuição da participação política e do que foi justamente chamado uma crise da representação política. Os eleitores não se sentem mais representados; o que expressam ao denunciar uma classe política que não teria outro objetivo que o seu próprio poder e algumas vezes o enriquecimento pessoal dos seus integrantes. A consciência da cidadania se enfraquece, seja porque muitos indivíduos se sentem mais consumidores do que cidadãos e mais cosmopolitas do que nacionais, seja, ao contrário, porque um certo número dentre eles se sentem marginalizados ou excluídos de uma sociedade à qual não se percebem como participantes, por razões econômicas, políticas, étnicas ou culturais (Touraine, 1994, p. 18).

O fato de um quarto de século mais tarde estas palavras ainda parecerem fazer todo sentido comprova a atualidade do pensamento do sociólogo francês Alain Touraine, e a pertinência de ainda nos debruçarmos sobre seu pensamento, 
usualmente relacionado à sociologia da ação. É o que explicitam os textos reunidos no dossiê "A sociologia de Alain Touraine", dedicado ao pensamento e à trajetória do autor francês, com o qual se abre este número 106 de Lua Nova. Os seis artigos e a entrevista que compõem o dossiê foram reunidos e organizados por Flávio Mendes e Ricardo Festi, com a ajuda de Rubia Ramos.

No primeiro texto, Touraine: le sujet contre le système, François Dubet se dedica a elaborar uma visão geral da sociologia tourainiana a partir da tensão constante entre o sujeito e o sistema, que atravessa todas as fases de seu trabalho. A oportunidade de compartilhar, desde os anos de 1970 , diversos projetos de pesquisa com o intelectual francês, permite a Dubet conhecer de perto as bases do projeto acionalista e sua forma de ação cotidiana.

Em seguida, em Alain Touraine y la historia, Danilo Martuccelli também propõe uma abordagem transversal da obra de Touraine. Ele destaca a centralidade da problemática da história, base de suas reflexões sobre atores sociais e tipos de sociedades contemporâneas. Martuccelli sustenta que nem mesmo o processo de revisão ao qual Touraine submeteu sua proposta de teoria social nas últimas três décadas abalou sua convicção de que são os conflitos sociais que movem a sociedade e produzem a história.

No terceiro artigo, as contribuições de Touraine para o desenvolvimento da sociologia do trabalho na França e no Brasil são discutidas por Ricardo Festi. Em Um desejo de história: a sociologia do trabalho de Alain Touraine (1948-1973), encontramos uma exposição bem detalhada do contexto em que se deu a reorganização da sociologia como disciplina acadêmica nos dois países, no pós-guerra, a partir de uma agenda mais ou menos comum. As condições de circulação internacional de Touraine e seus interlocutores brasileiros são igualmente descritas por Festi, que se baseia numa rica consulta a arquivos.

As interações entre Touraine e a sociologia brasileira também são tema do quarto artigo Alain Touraine e o Brasil: atores sociais e dependência em diálogos dos anos 1970, de Flávio Mendes. O autor analisa como a assimilação do debate sobre a dependência 
latino-americana influenciou a formulação de um modelo de abordagem específico sobre a modernização periférica, presente tanto em textos de Touraine quanto em teses sobre o Brasil que o sociólogo orientou durante a década de 1970.

No quinto artigo, Entre a América Latina e uma proposta de emancipação: os conceitos de cultura democrática e sujeito na obra da Alain Touraine, Rubia Ramos demonstra como os estudos do sociólogo francês sobre a América Latina contribuíram para a formulação das noções de sujeito e democracia, que ganharam importância em suas obras mais recentes. A autora aborda a teoria social tourainiana como um esforço permanente de crítica à experiência moderna e discute os alcances e limites de sua proposta para pensar a democracia na contemporaneidade.

Em seguida, em Conflito e movimentos sociais no acionalismo de Alain Touraine, Angelina Peralva descreve os fundamentos teóricos da abordagem acionalista tourainiana. Elaborada entre os anos 1950 e 1960, ela serviu de base ao longo das décadas posteriores para suas pesquisas sobre o movimento operário, os novos movimentos sociais e o sujeito. Alvo de sucessivas atualizações, o acionalismo manteve inalterados alguns de seus pilares, como a aposta na centralidade da ação social, e de seu potencial transformador diante das estruturas. Peralva reflete, enfim, sobre a pertinência da proposta de Touraine para o estudo de movimentos sociais contemporâneos.

O dossiê se encerra com uma entrevista, na qual Touraine responde a questões de Flávio Mendes e Ricardo Festi sobre sua trajetória em instituições de ensino e pesquisa francesas e seu intercâmbio com a América Latina. O sociólogo também expõe sua visão acerca de temas atuais, sobre os quais se concentram seus últimos textos.

Este número da revista Lua Nova conta ainda com dois artigos avulsos que abordam diferentes aspectos dos problemas decorrentes da reflexão sobre questões nacionais e seu impacto para além das fronteiras. No artigo A questão curda na guerra da Siria: dinâmicas internas e impactos regionais, Reginaldo Mattar Nasser e William Moraes Roberto abordam a identidade curda 
e seus reflexos, tanto nas tensões políticas internas de seus movimentos, quanto na região do Oriente Médio.

Por fim, este número fecha com o artigo Caminhos cruzados: marxismo e nacionalismo no Brasil e no Peru (1928-1964), no qual André Kaysel argumenta que a análise do marxismo de matriz comunista e o nacionalismo popular no Brasil e no Peru é um bom caminho para quem quer compreender o universo ideológico das esquerdas latino-americanas no século XX.

Cada um dos artigos que integram este número, inclusive os do dossiê, foram avaliados por ao menos dois pareceristas, a quem muito agradecemos.

Faz-se necessário anunciar, ainda, antes que os leitores se debrucem nos artigos da revista, que este número inaugura um novo ciclo na Lua Nova, com dois novos integrantes no comitê de redação: Brasílio Sallum Jr., da Universidade de São Paulo, e Flávia de Campos Mello, da Pontifícia Universidade Católica de São Paulo, que vêm somar-se a Pedro Meira Monteiro, da Princeton University. Estes dois novos pesquisadores entraram no lugar de Élide Rugai Bastos e Rossana Rocha Reis, que deixaram de fazer parte do comitê editorial ao final do ano 2018, após uma década de dedicação à revista. Sem a colaboração destas duas pesquisadoras, que foram também editoras entre 2009 e 2015, Lua Nova não teria alcançado o patamar elevado em que se encontra hoje, com excelentes níveis de qualificação, de acordo com os índices do Qualis Periódicos, nas mais diversas áreas.

\section{BIBLIOGRAFIA}

TOURAINE, Alain. 1994. Qu'est-ce que la démocratie? Paris: Fayard.

\section{Bruno Konder Comparato}

éprofessordoDepartamentodeCiênciasSociaisdaUniversidadeFederaldeSãoPaulo(Unifesp). Guarulhos, SP, Brasil. E-mail <bruno.comparato@unifesp.br>

Orcid: 0000-0001-9356-0362 http://dx.doi.org/10.1590/0102-007010/106 